\title{
THE ECONOMICS OF POVERTY IN POOR COUNTRIES
}

\author{
Partha Dasgupta \\ University of Cambridge \\ and \\ Beijer International Institute of Ecological Economics, Stockholm
}

Contents:

Abstract

1. Orthodox Dichotomies and their Limitations

2. The Magnitude of World Hunger

3. Undernourishment and Poverty Traps

4. Communal Rights and the Local Commons

5. Institutional Failure: Poverty and Degradation of the Environmental-Resource Base

6. Fertility Behaviour and the Structure of Households

7. Poverty, Fertility, and the Local Environment

8. Living Standards Indices

9. Conclusions

References

Discussion Paper

No. DEDPS/9

January 1998
The Suntory Centre

Suntory and Toyota International Centres for Economics and Related Disciplines

London School of Economics and Political Science Houghton Street

London WC2A 2AE

Tel.: 020-7955 6674

This article was presented at a Symposium organised by the Editorial Board of Scandinavian Journal of Economics in Oslo, January 1997 (revised November 1997), to celebrate the journal's $100^{\text {th }}$ anniversary next year, and will appear in the Special Centenary Issue. I am most grateful to the participants and referees for their comments and, in particular, to Kaushik Basu, Thor Gylfason, and Assar Lindbeck. 


\section{Abstract}

This article examines the links that have recently been studied between poverty, high fertility and undernourishment, on the one hand, and degradation of the local environmental resource base and civic disconnection, on the other, in poor countries. An account is offered of a number of pathways involving positive feed-backs that create poverty traps, into which certain identifiable groups of people in an economy can get caught even when the economy in the aggregate experiences economic growth. The relevant policy implications are noted.

Keywords: Poverty traps, positive feed-back, undernourishment, property rights, fertility, the commons, local democracy, civil liberties

JEL Nos.: O1, Q1, Q2.

(C) by Partha Dasgupta. All rights reserved. Short sections of text, not to exceed two paragraphs, may be quoted without explicit permission provided that full credit, including $(\odot$ notice, is given to the source. 


\section{Orthodox Dichotomies and Their Limitations}

Development economics has traditionally been as much concerned with the study of resource allocation mechanisms harbouring large-scale poverty, as it has been with seeking to alter such mechanisms in ways that would enable people to lift themselves out of poverty. If public policy has loomed large in the subject, so has positive analysis of poverty. Unhappily though, the social and ecological context in which such analyses have most frequently been undertaken were, until recently, inappropriate. Thus, in particular, the links connecting poverty, high fertility and undernourishment, on the one hand, and degradation of the local environmental-resource base and civic disconnection, on the other, remained unexplored. ${ }^{1}$ It should come as no surprise that as a group development economists have come under periodic criticism from anthropologists, demographers, ecologists, nutritionists, and political scientists.

I have a reason for pointing to this particular weakness in development economics: much of my own work in recent years has been an attempt to understand the links that bind these routine features of the lives of the poor in poor countries. ${ }^{2}$ So if the account I will sketch below of recent developments in the subject seems biased, this is because it is biased. My aim is not to survey development economics, rather, it is to try to present a unified treatment of a set of interrelated problems that are faced by the poorest in poor countries. $^{3}$

The literature on macroeconomic growth has been much concerned with the question whether in recent years nations have shown signs of convergence in their living standards, and if they have not, then why not. The theme I will elaborate upon here bears a faint resemblance: we will ask if an economy can harbour poverty traps even when in the aggregate it grows, and we will identify an overarching mechanism by which it can. Much

${ }^{1}$ The survey article on development economics by Stern (1989) reflects this neglect.

${ }^{2}$ Dasgupta (1982, 1990, 1993, 1995a,b, 1996, 1997a,b,c), Dasgupta and Ray (1986, 1987), and Dasgupta and Mäler (1991).

${ }^{3}$ The exposition here borrows freely from the works I have cited above. Space forbids that I offer extensive references. For them, see Dasgupta (1993). 
recent development economics has quantified poverty and identified the poor. In contrast, the findings I will report here concern pathways by which people become poor and remain poor.

I have another motive for presenting developments in development economics in the way I will here. In recent years modern economics has come under regular attack from both within (e.g. Heilbroner and Milberg, 1995) and without (e.g. Cassidy, 1996). I want to defend modern economics here, because it is eminently defendable. So I will also use this occasion to demonstrate that the economist's lens has enriched our understanding of the lives of the poor, in particular, it has enabled us to identify connections among observed phenomena that earlier went unexamined.

To take an example, orthodox discussions of economic institutions (e.g. Heilbroner, 1993) are conducted in the context of a markets-versus-State dichotomy. This is so restrictive as to be misleading. Societies throughout the world have fashioned intermediate, often criss-crossing institutions, such as the household, extended-family and kinship networks; civic, commercial, and religious associations; charities; production units; and various layers of what is known as government. Each serves functions at which the others are not so good. They differ not only in terms of the emotional bonds that connect members, but also in regard to the information channels that serve them, the kinds of agreements that bind them, and the investment outlays and severence costs that help sustain them. Their elucidation, in particular our increased understanding of their strengths and weaknesses, has been one of the most compelling achievements of economics over the past twenty-five years or so.

In a similar vein, orthodox discussions of property rights (e.g. Heilbroner, 1993) cling to a private-versus-public dichotomy. As we will see, this too is misleading: societies throughout the world have allowed people to hold assets in other forms of ownership, for example, ownership among members of local communities. So when development economists today talk of the need for institutional reforms and reforms in the structure of property rights, they include in it the need for strengthening those institutions that complement the pairs that define the orthodox dichotomies.

There is another dichotomy that has been the cause of mischief. Some (e.g. World 
Bank, 1986) have located the cause of poverty and hunger at production failure owing to a suppression of markets, while others have identified it with distributional failure (e.g. UNDP, 1994). Among the economic policies that suggest themselves from this dichotomy are, on the one hand, measures that widen markets and reduce traditional distortions, and a variety of "social security" measures, on the other. But these two extreme viewpoints encourage us to regard future well-being and an equitable distribution of current wellbeing as necessarily consonant with each other. If conducted with care, certain policies that encourage economic growth (e.g. the provision of basic infrastructure) can indeed improve the distribution of well-being. Similarly, certain policies that improve the distribution of well-being (e.g. primary education) do improve overall economic performance. Both theory and empirics testify to them. But the two social goals are not invariably consonant with each other. In those circumstance where they are not, citizens face a tradeoff between them, and a choice has to be made over the combinations that are available.

Much of the evidence and analysis I will offer in this article bears on sub-Saharan Africa and the Indian sub-continent. They are currently the two poorest regions, comprising nearly 2 billion people. Moreover, approximately 75 percent of the poor in subSaharan Africa and the Indian sub-continent are rural people, obtaining their livelihood directly from the environmental-resource base, most especially agriculture. So it pays to study the rural poor. ${ }^{4}$

The plan of the paper is as follows:

Section 2 will contain a summary of evidence on the magnitude and incidence of world poverty. Sections 3-6 will explore various pathways by which people become poor, remain poor, and take actions to cope with poverty. Specifically, in Section 3 we will study the connection between undernourishment and a person's capacity to work and show that it forms one pathway by which poverty traps are created. In Sections $4-5$ we will look at the dependence of the rural poor in poor countries on common-property resources and see how the very process of economic growth (conventionally measured) can result in the

${ }^{4}$ I will not discuss urban poverty because I am inexpert on the matter. World Bank $(1991,1994)$ contain excellent analyses of the main problems there. 
breakdown of communitarian arrangements, making certain sections of the population (viz. women, children, and the old) especially vulnerable to economic shocks. Sections 6-7 will focus on fertility behaviour. I will suggest that the links between poverty, high fertility, and environmental deterioration may well constitute yet another pathway by which people can get trapped in poverty.

For each of the problems we will study, public policies will suggest themselves and we will take note of them at appropriate places. But policies need to be evaluated. So one needs an evaluation criterion. Conventional indices (e.g. gross national product) are known to be very deficient. In response to this, environmental economists have extended the concept of net national product (NNP) to include resource depletion and environmental deterioration. Section 8 will review this idea. I will argue that if environmental and population problems have been much neglected by mainstream development economists, it may well be because they have been studying wrong economic indices.

Finally, in Section 9 I will make a few remarks about certain wider issues in political economy.

\section{The Magnitude of World Hunger}

Visitors to the Indian sub-continent routinely observe emaciated beggars on the streets of large cities. They are the economically disenfranchised. I do not know their proportion in today's populations, but we do know that, at a conservative estimate, over 600 million people in Asia, Africa and Latin America are undernourished. Table 1 offers two estimates of the magnitude of world poverty, based on two alternative criteria for poverty. The "extreme poor" (annual income less than 275 international dollars in the mid1980s) were some 630 million in number, comprising 18 percent of the total population of poor countries. The "poor" (annual income less than 370 international dollars in the mid$1980 \mathrm{~s}$ ) were 1,110 million in number, comprising a third of the total population of poor countries.

Table 1 also provides estimates of poverty gaps in various regions of the poor world. Notice that even in South Asia and sub-Saharan Africa a mere 4 percent growth in income, if it were distributed efficiently among the poor, would eliminate extreme poverty.

There are other estimates of world poverty, based on income, but they are not 
dissimilar. For example, IFPRI (1995) suggests that 800 million people, comprising 20 percent of the poor world's population, currently suffer from food insecurity. Of course, the idea of a poverty line, whether or not it is based on income, can be criticised. But the practical advantages of thinking in terms of a line that divides the "poor" from those who are "not poor" are considerable. So the concept is used widely.

The deficiencies of income-based concepts of poverty are, however, not so easy to ignore (Morris, 1979; Sen 1983). For this reason other indicators of poverty have frequently been advocated. What is striking, though, is that estimates of the magnitude of world poverty are similar even when such other criteria are put to work. For example, FAO (1992) have calculated that some 785 million people (of whom approximately 530 million are in South and East Asia, and 170 million are in sub-Saharan Africa) suffer from dietary energy deficiency. About 1 billion people in poor countries have no access to modern health services, and about 1.3 billion people do not drink potable water. Moreover, estimates based on anthropometric indicators (James et al., 1992), are not dissimilar. Approximately 185 million children under six years are currently thought to be seriously underweight. Deficiencies in micro-nutrients are even more pervasive. Approximately 1.2 billion people (and more than half the number of pregnant women in poor countries) suffer from anemia; 600 million suffer from iodine deficiency disorders, and 125 million preschool children suffer from vitamin-A deficiency.

Eradication of micro-nutrient deficiencies would not demand much resources. Rough calculations indicate that less than 0.3 percent of world income is all that would be required on an annual basis. A problem of far greater magnitude is the availability of dietary energy. The general consensus among nutritionists is that, barring diets that build on root and tuber crops, those that contain adequate energy are adequate also in their protein content. Among the world's poor, cereals (viz. wheat, rice, maize, and barley) as food are the main sources of nutrition, accounting for more than 50 percent of their energy intake. So when people worry about food prospects in, say, the year 2020 or 2050 , they typically worry about the availability of cereals. ${ }^{5}$

${ }^{5}$ I have gone into these issues in greater detail in Dasgupta (1997b). 


\section{Table 1}

Magnitude of poverty (1985)

Extremely Poor ${ }^{\mathrm{a}}$

Region

$\begin{array}{lll}\begin{array}{l}\text { Number } \\ (\mathrm{m})\end{array} & \text { HI } & \text { PG } \\ & (\%) & (\%)\end{array}$

Sub-Saharan

Africa

East Asia

China

South Asia

India

Middle East \&

North Africa

Latin America

\& the

Caribbean

50

$12 \quad 1$

70

191

All Develop-

ing Countries

630

Poor

Number HI PG

(m)

(\%)

180

$47 \quad 11$

280

(210)

$\begin{array}{ll}20 & 1 \\ 20 & 3\end{array}$

520

(420)

$51 \quad 10$

$55 \quad 12$

60

$31 \quad 2$

$21 \quad 1$

60

2

(\%) 


\section{Undernourishment and Poverty Traps}

Rural households in poor countries are vastly more circumscribed in their ability to do things than their counterparts are in rich countries. By this I do not only mean that they have less incomes, but that they also face more stringent constraints in their ability to engage in economic transactions. There is, for example, an extreme paucity of infrastructure, such as roads and other means of communication. Villages resemble enclaves; they are often not integrated with the rest of the economy. ${ }^{6}$ This in turn means that both insurance and credit facilities for the rural poor are greatly circumscribed. Formally, it is to say that correlations among environmental risks within villages can be "large" and, so, the scope for pooling risks "small"; which is another way of saying that both insurance and credit markets can be relatively thin. As always, even within poor societies the poor are less able to insure themselves against adverse circumstances than the rich. They are also less able to obtain credit: they own less in the way of collateral.

The link between household poverty and an inability to obtain insurance and credit is one pathway by which people can fall into a poverty trap. The link creates a positive feed-back (Myrdal, 1944, called such feed-backs cumulative causation), one which enables those who have assets to move further ahead, even while it prevents those who do not have assets to be trapped in poverty (Braverman and Stiglitz, 1989).

But there are more fundamental issues in the economics of food deficiency and poverty traps. Modern nutrition science has shown that undernourishment is not necessarily the immediate cause of death. Relatively low mortality rates can co-exist with a high incidence of undernutrition, morbidity and, thus, low capacity for work. ${ }^{7}$ For this reason the classical notion of "subsistence wage" finds little resonance in the modern literature. Undernutrition is not the same as starvation. So the economics of undernutrition is not the same as the economics of famines. Famines are disequilibrium phenomena. They cannot persist, for the reason that their victims do not survive. In contrast, even a

${ }^{6}$ Rudra (1984) and Platteau and Hayami (1997) offer brisk substantiations of this.

${ }^{7}$ Spurr $(1988,1990)$ contain authoritative statements on the matter. The modern classic on childhood malnutrition is Waterlow (1992). 
widespread incidence of undernourishment can persist indefinitely: people are capable of living and breeding in circumstances of extreme poverty. But if over an extended period of time a person is to convert potential labour power into actual labour power of any specified, physiologically admissible amount, they require among other things nutrition of a corresponding quality and magnitude over that period. Dasgupta and Ray $(1986,1987)$ showed that the link between nutritional status and the capacity to work creates a particularly menacing pathway by which poor households can get trapped in poverty. ${ }^{8}$ The undernourished are at a severe disadvantage in their ability to obtain food: the quality of work they are able to offer is inadequate for obtaining the food they require if they are to improve their nutritional status. Thus, over time undernourishment (more generally, illhealth) can be both a cause and consequence of someone falling into a poverty trap. Moreover, such poverty can be dynastic: once a household falls into a poverty trap, it can prove especially hard for descendents to emerge out of it, even if the economy in the aggregate were to experience growth in output for a while.

Dasgupta and Ray $(1986,1987)$ also showed that if the distribution of assets (e.g. land) is highly unequal in an economy that is poor, certain patterns of egalitarian redistribution of assets can enhance economic growth. Analyses of international crosssection data offer support for this finding: initial inequality of assets, as measured by the distribution of land, has been found to exert a significant negative impact on subsequent growth (Deininger and Squire, 1997).

The source of such positive feed-backs and poverty traps as I have described is the large "maintenance requirement" of living. As is well-known, something like 60-75 percent of the energy intake of someone in nutrition balance goes toward maintenance; the much smaller 40-25 percent is spent on "discretionary" activities, such as work and play (see e.g. WHO, 1985). Large maintenance requirements are a reason why, in poor societies, we would expect to see the emergence of inequality among people who may have to begin with been very similar. In short, a society's poverty could in itself be a cause of stark inequality.

${ }^{8}$ The theory is developed more fully in Dasgupta $(1993,1997 a)$. 
Notice the unusual causal direction being identified here. It is a commonplace to say that poverty among households is a reflection (even a consequence) of economic inequality. I am talking of a possible reverse causality: from poverty to inequality.

There are, of course, implicit qualifications in the account of poverty traps I am offering here. I have confined myself to central tendencies. The cycle of poverty is not inevitable. Luck can play a role, and even the poorest of households have been known to pull themselves out of the mire. But the nutrition-based theory of poverty traps has explanatory power. It offers an explanation of the modern incidence of poverty and undernutrition amidst plenty; and it explains how and why, despite the secular growth in income and food production that the world as a whole has enjoyed since the end of the Second World War, 15-20 percent of the world's population currently suffers from food deficiency. ${ }^{9}$

But there are problems within problems in the economics of poverty. Economic growth within a society can impose additional pressures, enabling poverty traps to have an even greater stranglehold over the lives of the poor in that society. This can come about because of a shift from cereal to meat in the dietary habits of those whose incomes rise. Table 2 provides an indication of food-feed shares of cereals in 40 poor countries and 26 industrial market economies in the mid-1980s. In 1980, consumption of cereals in the former group was 208 million metric tons, whereas cereals as feed amounted to only 5 million tons. In contrast, the corresponding figures in the latter group were 104 and 288 million tons. As the table also shows, income elasticities of demand for cereals as food and feed in the poorest countries are 0.23 and 0.75 , respectively, and in industrial market economies they are 0.03 and 0.14 . All this is in accordance with what one would expect.

However, as is well known, animal metabolism (especially that of cattle) is not very efficient in the conversion of plant food. Thus, growth in average income generates an

${ }^{9}$ Fogel (1994) has also offered such an account as this, but to explain why beggars constituted as much as a fifth of the populations of ancien regimes in late eighteenth century France. The picture of begging our analysis draws contains both physiological and behavioral adaptation with vengeance. It tells us that emaciated beggars are not lazy: they have to husband their precarious hold on energy. 


\section{Table 2}

Competition between Food and Feed

Poor Countries
Industrial Market Economies

(1) Aggregate cereal demand (million metric tons)

food

feed
208

5

3.8

feed

food

(2) Rate of growth of demand

for cereals (1966-80)

0.4

1.3

feed

(3) Rate of growth of per capita demand for cereals (1966-80)

food

(4) Income elasticity of demand for cereals

food

0.23

0.75

feed
104

288

Source: Yotopoulos (1985), Tables 1-2. 
incentive for farmers to shift land away from the production of food-grain toward that of cereals as feed-grain and toward grazing grounds. In terms of calories, the shift is disproportionate because of the inefficient conversion process. This goes to impoverish the poor further because, among other things, grain prices rise to equilibrate the market. As an example of how sensitive to availability grain prices can be, one should recall that the world food crisis of 1972-74 involved a 3 percent shortfall in grain production, accompanied by a 250 percent price increase. Yotopoulos (1985) has made the point that increases in the number of middle-income people exacerbates the incidence of malnutrition among those without assets, because the composition of demand shifts in an adverse way. There are indications that this is a potent force. For example, the annual rate of growth of cereal consumption in the poorest countries during $1966-80$ was 2.9 percent, whereas that of feed was 3.8 percent. These are not comforting statistics.

\section{Communal Rights and the Local Commons}

The foregoing analysis suggests why a form of asset ownership of particular significance to the rural poor is communal. Hardin's (1968) famous observation on the fate of common-property resources, that they erode because people free-ride on others, was telling for such globally mobile resources as the atmosphere and the open seas. However, the "tragedy of the commons" is not necessarily an apt metaphor for geographically localized common-property resources, such as irrigation water, woodlands and local forests, threshing grounds, grazing fields, inland and coastal fisheries, and swidden fallows. For it has been discovered that, typically, the local commons are not open for use to all. They are not "open access" resources; in most cases they are open only to those having customary rights, through kinship ties, community membership, and so forth. Social capital, viewed as a complex of interpersonal networks (Coleman, 1990; Putnam, 1993), is telling in this context: it hints at the basis upon which cooperation has traditionally been built. Thus, from the theory of games we have known for some time that the local commons can in principle be managed efficiently by the users themselves: there is no obvious need for some agency external to the community of users (e.g. the State) to assume a regulatory role, nor is there an obvious need for privatising the assets. A large body of recent evidence confirms the theory's prediction, in that members of local communities 
have often cooperated in protecting their commons from excessive use. ${ }^{10}$

Why should we expect such a marked difference between the fates of local and global common-property resources? One reason is that individual use is more easily observable by others when the resource is not spread out spatially; which means that it is easier to prevent people from free-riding on the local commons. (Contrast the use of a village tube-well with the littering of streets in a metropolis; or cattle-grazing in the village commons with deforestation on mountainous terrains). However, bargaining, enforcement, and information costs also play a role in the relative efficacy of the various rules that can in principle be invoked for sharing the benefits and burdens associated with an efficient use of common-property resources. Thus, it matters whether the users know one another (contrast a village grazing ground with ocean fisheries); it matters whether increased mobility makes future encounters among group members more uncertain (contrast a traditional village with a modern metropolis); and it matters whether population pressure makes transaction costs exceed the benefits of cooperation. The confirmation of theory by current evidence on the fate of different categories of common-property resources has been one of the most pleasing features of modern economic analysis.

Are common-property resources extensive in poor countries? As a proportion of total assets, their presence ranges widely across ecological zones. In India they appear to be most prominent in arid regions, mountain regions, and unirrigated areas; they are least prominent in humid regions and river valleys. There is, of course, an economic rationale for this, based on the common human desire to pool risks. An almost immediate empirical corollary is that income inequalities are less where common-property resources are more prominent. However, aggregate income is a different matter, and it is the arid and mountain regions and unirrigated areas that are the poorest. This needs to be borne in mind when government policy is devised. As may be expected, even within dry regions, dependence on common-property resources declines with increasing wealth across

${ }^{10}$ There is now a large empirical literature recording both the successes and failures of common-property resource management. Feeny et al. (1990), Ostrom (1990), and Baland and Platteau (1996, chs. 10-13) offer good reviews of the findings. 
households.

Jodha $(1986,1995)$ used data from over eighty villages in twenty-one dry districts from six tropical states in India to estimate that, among poor families, the proportion of income based directly on the local commons is for the most part in the range 15-25 percent. Moreover, as sources of income, they are often complementary to private-property resources. Common-property resources also provide the rural poor with partial protection in times of unusual economic stress. For landless people they may be the only non-human asset at their disposal. A number of resources (such as fuelwood and water, berries and nuts, medicinal herbs, resin and gum) are the responsibility of women and children.

A similar picture emerges from Hecht, Anderson and May (1988), who describe in rich detail the importance of the extraction of babassu products among the landless (and most especially, the women among them) in the Brazilian state of Maranhão. These products are an important source of cash income in the period between agricultural-crop harvests. "11

So studies have confirmed that the local commons are quite prevalent in rural areas of poor countries. Empirical studies have also confirmed that resource users in many instances cooperate, on occasion through not undemocratic means, so as to ensure that the resource base is not eroded. Attempts have also been made by social scientists to explain observed asymmetries in the distribution of benefits and burdens of cooperation in terms of underlying differences in the circumstances of the various parties. For example, in her study of collectively-managed irrigation systems in Nepal, Ostrom (1996) has explained observed differences in benefits and burdens among users (e.g. who gets how much water from the canal system and who is responsible for which maintenance task) in terms of such facts as that some farmers are headenders, while others are tailenders. Ostrom (1990) has also tried to explain why cooperation has failed to get off ground where it did not get established.

Wade (1988) has conducted an empirical investigation of community-based allocation rules over water and the use of grazing land in a sample of forty-one South

${ }^{11}$ For a similar picture in the West African forest zone, see Falconer (1990). 
Indian villages. He found that downstream villages (i.e. those facing especial water scarcity) had an elaborate set of rules, enforced by fines, for regulating the use of water from irrigation canals. Most villages had similar arrangements for the use of grazing land. In an earlier work on the Kuna tribe in the Panama, Howe (1986) described the intricate set of social sanctions that are imposed upon those who violate norms of behaviour designed to protect their source of fresh water.

Behaviour dictated by social norms could seem incongruent with the democratic ideal, but the theory of repeated games has shown that there can be a close connection between the two. Social norms can be viewed as self-enforcing behavioural strategies. Even if a resource allocation rule among members of a community were chosen democratically, there would be a problem of enforcement. Norms are a way the rule could be enforced without the community having to rely on the coercive powers of a higher authority (e.g. the State).

This said, it is important to caution against romanticising communitarian arrangements over the use of the local commons. For example, McKean (1992) has noted that in common-property systems almost everywhere, entitlements to the products have mostly been based on private holdings. They have thus reproduced the inequality in private wealth. Beteille (1983) contains examples of how access is often restricted to the privileged (e.g. caste Hindus in India). Rampant inequities exist in rural community practices. I am laying stress upon the fact that the local commons are often not unmanaged; I am not suggesting that they are invariably managed efficiently, nor that they are necessarily managed democratically, nor that they are inevitably managed in ways that involve an equitable distribution of benefits and burdens. Good management of the commons requires more than mere local participation; it needs enlightened government engagement as well.

Not surprisingly, information about the ecology of the local commons is usually in the hands of those who, customarily, have made use of them. This means that as a general rule decisions concerning the local commons ought to be left in the hands of the users themselves. It forms one reason why it is so important that local democracy be encouraged to flourish in rural communities of poor countries. The local commons will remain the 
single source of vital complementary and insurance goods for poor people for some time to come. We may conclude from this that a duty of the State is to help develop rural infrastructure and markets for credit and insurance, each of which could be expected to lessen the community's reliance on the commons. However, there is little case for centralized command and control over the use of the commons; quite the contrary, there is a case for helping the growth of local democracy. As women are often the ones to work on the commons, they would be expected to know more than others about the ecological processes upon which their communities depend. So a task of the State is to help women participate in the democratic process. More generally, the State should be obliged to ensure that local decision-making is made in an open way. It would help prevent the economically powerful among rural communities from usurping control over such decisions. This tension - the simultaneous need for increased decentralization of rural decision-making, and for State involvement in ensuring that the seat of local decisions is not usurped by the powerful - poses a central dilemma in the political economy of rural poverty. Local democracy, income security, and environmental protection would appear to be tied to each other.

\section{Institutional Failure: Poverty and Degradation of the Environmental-Resource Base}

But much else has not gone well: case-studies undertaken both in the Indian subcontinent and in sub-Saharan Africa have shown deterioration in the environmentalresource base in the poorest regions. Why and how has this happened?

A recent intellectual tradition argues that the reason the poor today degrade their environmental-resource base is that their poverty forces them to discount future incomes at unusually high rates (see, for example, Bardhan, 1996: 62). I do not know of much evidence in support of this. In any event, the argument would apply to the poor of the past as well. If it were valid, they would hardly have invested in their resource bases to the extent they appear to have done, the fruits of which we enjoy today. In what follows I will identify a less parsimonious, but hopefully more persuasive, explanation for contemporary resource depletion: low rates of return on private investment in the resource base owing to institutional failure.

There are a number of systematic features of institutional failure in poor countries 
that have been easy enough to detect. Governments in many poor countries, most especially those in sub-Saharan Africa, have for long discriminated against agriculture, creating strong disincentives for farmers to invest in it. Export quotas, over-valued exchange rates, and state marketing boards that purchase agricultural produce at artificially low prices have ensured that something like 50 percent of the agricultural income of poor countries has been transferred to the rest of their economies through the years. ${ }^{12}$

Peasants' property rights to the agricultural-resource base have also been insecure in many poor countries (e.g. China). This has created further disincentives for farmers to invest in the land they till. Over the past 10 years, grain production per head in China has reached a plateau. China's grain imports have risen with her income, and a natural question, "Who will feed China", now appears routinely in publications (e.g. Brown, 1995). Prosterman, Hanstad and $\mathrm{Li}$ (1996) trace China's faltered agricultural performance to the weaknesses in the structure of property-rights in agricultural land. Farmers' rights in China to the land they till even now do not extend beyond some 15 years. So they have little incentive to engage in long-term agricultural investment.

There is another type of institutional failure that disenfranchises the poor from an economy even while in the aggregate the society of which they are members enjoys economic growth: breakdown of communitarian norms. The point is that if you are steeped in social norms of behaviour and understand community obligations, you do not calculate every five minutes how you should behave. You follow the norms. This saves on costs all round, not only for you as an "actor", but also for you as "policeman" and "judge". It is also the natural thing for you to do if you have internalized the norms. But this is sustainable so long as the background environment remains approximately constant. It will not be

${ }^{12}$ See Krueger, Schiff and Valdes (1988). The classic on the errors of state marketing boards is Bauer and Yamey (1968). Pinstrup-Andersen (1994) contains an excellent summary of the current food situation in the world. There are other, systemic reasons, having to do with the structure of social life, why there is little scope for individual initiative to be rewarded in sub-Saharan Africa's rural economies. Platteau and Hayami (1997) offer an account of them and argue that they in large measure explain the economic decline of that region over the past twenty-five years. 
sustainable if the social environment changes suddenly and trust is broken. You may even be destroyed. It is this heightened vulnerability, often more real than perceived, which is the cause of some of the greatest tragedies in contemporary society.

There are other, related sources that trigger the process of resource degradation and economic disenfranchisement among the poor. For example, an erosion of the local commons can come in the wake of shifting populations accompanying the development process itself. As economic opportunities outside the village improve, those with lesser ties (e.g. young men) are more likely to take advantage of them and make a break with customary obligations. Those with greater attachments (e.g. women) would perceive this and thereby discount at a higher rate the benefits that could be expected from complying with agreements. Either way, norms of reciprocity could be expected to break down, making certain groups of people (e.g. women) worse off. But an erosion of the local commons can also come about in the wake of technological change, an increase in population (and the consequent pressure on these resources), unreflective public policies, and more directly, predatory governments and thieving aristocracies. There is now an accumulation of evidence on this range of causes. In what follows, I will present a sketch of the findings in four sets of studies, covering three continents.

1. In his work on a sample of villages in the drylands of India, Jodha $(1986,1995)$ noted that over a twenty-year period, starting in the early 1960 s, there had been a 25-60 percent decline in the area covered by the commons. This was in part due to the privatization of land, a good deal of which in his sample had been awarded to the rural non-poor. In an earlier work, Jodha (1980) identified the rise in the profitability of land from cropping and grazing as a central reason for increased desertification in the northern state of Rajasthan. Jodha argued that, ironically, it was government land reform programmes in this area, unaccompanied by investment in improving the productive base, that had triggered the process.

2. Ensminger's (1990) study of the privatization of common grazing lands among the Orma in northeastern Kenya showed that the transformation took place with the consent of the elders of the tribe. She attributes this willingness to changing transaction costs brought about by cheaper transportation and widening markets. The elders were, 
quite naturally, from the stronger families, and it does not go unnoted by Ensminger that privatization has accentuated inequalities.

3. In an earlier work on the Amazon basin, Feder (1977) described how massive private investment in the expansion of beef-cattle production in fragile ecological conditions had been supported by domestic governments in the form of tax concessions and provision of infrastructure, and loans from international agencies such as the World Bank. The degradation of vast tracts of forests was accompanied by the disenfranchisement of large numbers of small farmers and agricultural labourers from the economy. At best it made destitutes of traditional forest dwellers; at worst it simply eliminated them. ${ }^{13}$ The evidence suggests that during the decades of the 1960 s and '70s protein intake by the rural poor declined even while the production of beef increased dramatically. Some of the beef was destined for exports, for use by fast-food chains.

This said, I am not advocating a mono-causal explanation of the depletion of the Amazon forests. In a wider discussion of the conversion of forests into ranches in the Amazon basin, Schneider (1995) has demonstrated that the construction of roads through the forests (an instance of integration with outside markets) has been a potent force. The construction of roads greatly reduced transport costs between outside markets and the resource base in the Amazon. This in turn vastly increased individual incentives for opportunistic behaviour in a world with unsettled property rights.

4. In a summary of research findings on local irrigation in Nepal, Ostrom (1996) notes that systems that had been improved by the construction of permanent headworks were in worse repair, delivered substantially less water to the tail-end than to the head-end of the systems, and had lower agricultural productivity than the temporary, stone-treesand-mud headworks that had been constructed and managed by the farmers themselves.

Ostrom has an explanation for this. She suggests that, unless it is accompanied by counter-measures, the construction of permanent headworks alters the relative bargaining positions of the head-and tail-enders, resulting in so reduced a flow of benefits to the latter group that they have little incentive to help repair and maintain the headworks, something

${ }^{13}$ See also Hecht (1985). 
the head-enders on their own cannot do. Head-enders gain from the permanent structures, but the tail-enders lose disproportionately. Ostrom (1996) also notes that traditional farmmanaged systems sustained greater equality in the allocation of water than modern systems managed by such external agencies as the government and foreign donors.

The sources that were identified in the first three sets of studies as having transformed common-property resources into private resources differed considerably. Therefore, the pathways by which the transformation affected those with customary rights were different. Since the impact of these pathways to privatization on the poorest of the poor are confirmed by economic theory, the findings of these case-studies are almost certainly not unrepresentative. Many of the studies suggest that privatization of village commons and forest lands, while hallowed at the altar of economic efficiency, can have disastrous distributional consequences, disenfranchising entire classes of people. The point is a simple one: unless an appropriate fraction of the rents earned from the resource-base subsequent to privatization are given to the customary users, they become worse off. Ironically, case-studies also show that public ownership of such resources as forest lands is by no means necessarily a good basis for a resource allocation mechanism. Decisionmakers are in these cases usually far removed from site (living as they do in imperial capitals), they have little knowledge of the ecology of such matters, their time-horizons are often short, and they are in many instances overly influenced by interest-groups far removed from the resource in question.

All this is not to suggest that rural development is to be avoided. It is to say that resource allocation mechanisms that do not take advantage of dispersed information, that are insensitive to hidden (and often not-so-hidden) economic and ecological interactions, that do not take the long-view, and that do not give a sufficiently large weight to the claims of the poorest within rural populations (particularly the women and children and the old in these populations) are going to prove environmentally disastrous. It appears that, during the process of economic development there is a close link between environmental protection and the well-being of the poor. Elaboration of this link has been a compelling achievement at the interface of anthropology, economics and nutrition science.

\section{Fertility Behaviour and the Structure of Households}


Since the Second World War both the Indian sub-continent and sub-Saharan Africa have experienced unprecedented growth in population (since the early 1960s, the annual percentage rate of growth of population in the two regions have been 2.3 and 2.9, respectively). But there have been substantial differences in the experiences of the two regions (see Table 3). What account can we provide for each of the two features?

Economic demographers in recent years have identified gender-inequalities as an important component of the population problem in poor countries. In this regard, the focal point of the United Nations Conference on Population and Development in Cairo in September 1994, namely, women's reproductive rights and the means by which they could be protected and promoted (e.g. investing in women's education), is consonant with this new perspective. But the Cairo Conference came very near to treating the problems as identical. This was unfortunate, because it may have lulled many into thinking that there is a single cause for pro-natalist behaviour in the two regions. As with other phenomena in social life, there is more than one cause behind this one. Indeed, differences in women's educational attainments cannot explain the sharp differences in fertility rates between the Indian sub-continent and sub-Saharan Africa. There is more to the population problem.

This will come as no surprise to historical demographers. In his famous analysis of fertility differences between seventeenth-and eighteenth-century Northwest Europe on the one hand and modern pre-industrial societies on the other, Hajnal (1982) drew upon the distinction between "nuclear" and "joint" household systems. He observed that in Northwest Europe marriagenormally meant establishing a new household, which implied that the couple had to have, by saving or transfer, sufficient resources to establish and equip the new household. This requirement in turn led to late marriages. It also meant that parents bore the cost of rearing their children. Indeed, fertility rates in France dropped before mortality rates registered a decline, before modern family-planning techniques became available, and before women became literate (Coale, 1969). Hajnal contrasted this with the Asiatic pattern of household formation, which he saw as joint units consisting of more than one couple and their children.

Table 3 displays the broad regional differences in fertility behaviour in the contemporary world. I am not sure if Hajnal's taxonomy is adequate here. For example, it 


\section{Table 3}

Total fertility rates in the late 1980 s

\section{Total Fertility Rate}

Sub-Saharan Africa

$6-8$

India

4.2

China

2.3

Japan, and Western industrial democracies

$1.5-1.9$

Source: World Bank (1990). 
can be argued that the rules of inheritance are a critical factor governing interpersonal relations, and that differences in inheritance rules may provide some explanation for why households in sub-Saharan Africa are strikingly dissimilar to the "joint" household system that has for long been taken to be the hallmark of the Asiatic form. Of course, inheritance rules themselves require explanation, and it is tempting to search for this in the mode and technology of agricultural production (viz. hoe versus the plough), and thereby in ecological factors (e.g. soil quality, population density, rainfall, and availability of domesticatable animals). These are delicate matters of historical analysis, and the causal links are not well-understood. But Hajnal's account offers hints that have rightly been at the centre of what is often called the new household economics: it is to focus on the relative costs and benefits of procreation to various parties. ${ }^{14}$

One prominent motive for having children arises from they being an end. ${ }^{15}$ This motive has been much studied in economic demography (Becker, 1981). Other motives involve viewing children as productive assets. For example, in rural economies where the avenues for saving are highly restricted, or where public support for the elderly are weak, parents value children as a source of security in their old age (Cain, 1981). In poor countries children are also useful as sources of current income. This provides households in these parts with another motive for procreation. It has possible consequences that have only recently been explored in theoretical analyses. Let us see what they are.

There are several pathways by which reasoned fertility decisions at the level of every household (whether the decision is based on the desire to have children because they are ends, or because they are productive assets) could lead to an unsatisfactory outcome from the perspectives of all households. One such pathway arises from the fact that traditional practice is often perpetuated by conformism, or imitative behaviour. Procreation in closely-knit communities is not only a private matter; it is also a social activity, influenced by the cultural milieu. In many societies there are practices encouraging high

${ }^{14}$ Much work is currently being undertaken on how best to model the household. See, for example, Alderman et al. (1995).

${ }^{15}$ Vulgerly put, children are a durable consumption good. 
fertility rates which no household desires unilaterally to break. Such practice may well have had a rationale in the past, but not necessarily any more. It can then be that, so long as all others follow the practice and aim at large family sizes, no household on its own will wish to deviate from the practice; however, if all other households were to restrict their fertility rates, each would desire to restrict its fertility rate as well. In short, there can be multiple equilibria, and a society may get stuck in a self-sustaining mode of behaviour that is characterized by high fertility and low educational attainment, even when in principle this "same" society could have sustained a mode of behaviour characterized by low fertility and high educational attainment.

This does not mean that society will be stuck with it forever. As always, people differ in the extent of their absorption of traditional practice. There are inevitably those who, for one reason or another, experiment, take risks, and refrain from joining the crowd. They are the tradition-breakers, and they often lead the way. A concerted social effort (for example, a massive literacy and employment drive) can help dislodge such a society from the rapacious hold of high fertility rates to another equilibrium mode of behaviour where fertility is low. Exposure to other ways of living, through the media of radio and television, have been found to be effective also (Freedman, 1995).

But there are other pathways that lead to pro-natalist behaviour. Parental costs of procreation are "low" when the cost of rearing the child is shared among the kinship. In sub-Saharan Africa, "fosterage" within the kinship is a commonplace: children are not raised solely by their parents, the responsibility is more diffuse within the kinship group (Goody, 1982; Bledsoe, 1990). Fosterage in the African context is not adoption. It is not intended to, nor does it in fact, break ties between parents and children. The institution affords a form of mutual insurance protection in semi-arid regions. There is some evidence that, as savings opportunities are few in the low-productivity agricultural regions of subSaharan Africa, fosterage also enables households to smoothen their consumption across time ${ }^{16}$ In parts of West Africa upto half the children have been found to be living with

${ }^{16}$ This latter motivation has been explored by Serra (1996). 
their kin at any given time. Nephews and nieces have the same rights of accomodation and support as do biological offspring. There is a sense in which children are seen as commonresponsibility. However, the arrangement creates yet another free-rider problem if the parents' share of the benefits from having children exceeds their share of the costs. From the point of view of the parents, taken as a collective, too many children would be produced in these circumstances.

Related to this is a phenomenon that has been observed by Guyer (1994) in a Yaruba area of Nigeria. In the face of deteriorating economic circumstances, some women are bearing children by different men so as to create immediate lateral links with them. Polyandrous motherhood enables women to have access to more than one resource network.

In sub-Saharan Africa, communal land tenure of the lineage social structure offers yet another inducement for men to procreate. In addition, as conjugal bonds are weak, fathers often do not bear the costs of siring a child. Anthropologists have observed that the unit of African society is a woman and her children, rather than parents and their children. Often, there is no common budget for the man and woman. Descent in sub-Saharan Africa is, for the most part, patrilineal and residence is patrilocal (an exception are the Akan people of Ghana). Patrilineality, weak conjugal bonds, communal land tenure, and a strong kinship support system of children, taken together, are a broad characteristic of the region (Caldwell, 1991). In principle they provide a powerful stimulus to fertility. Admittedly, patrilineality and patrilocality are features of the northern parts of the Indian sub-continent also. But conjugal bonds are substantially greater there. Moreover, as agricultural land is not communally held, large family sizes lead to fragmentation of landholdings. In contrast, large families in sub-Saharan Africa are (or, at least were, until recently) rewarded by a greater share of land belonging to the lineage or clan.

\section{Population, Poverty and the Local Environment}

The poorest countries are in great part biomass-based subsistence economies. Production throughput is low. Much labour is needed even for simple tasks. Moreover, households there do not have access to the sources of domestic energy available to households in advanced industrial countries. Nor do they have water on tap. In semi-arid 
and arid regions, water supply is often not even close at hand. Nor is fuel-wood near at hand when the forests recede. This means that the relative prices of alternative sources of energy and water faced by rural households in poor countries are quite different from those faced by households elsewhere. In addition to cultivating crops, caring for livestock, cooking food and producing simple marketable products, members of a household may have to spend as much as five to six hours a day fetching water and collecting fodder and wood. These are complementary activities. They have to be undertaken on a daily basis if the household is to survive. Each is time-consuming. Labour productivity is low not only because capital is scarce, but also because environmental resources are scarce. From about the age of 6 years, children in poor households in poor countries mind their siblings and domestic animals, fetch water, and collect fuelwood, dung, and fodder. Children are then needed as workers by their parents, even when the parents are in their prime. To give a sense of the order of magnitude, in their study of work allocation among rural households in the foothills of the Himalayas, the (Indian) Centre for Science and Environment, C.S.E (1990), recorded that children between 10 and 15 years work one-and-a-half times the number of hours adult males do.

Indeed, children can add so much to household income that, in some places, they are costless to rear by the time they reach adolescence. Cain (1977) studied data from the village Char Gopalpur in Bangladesh. He estimated that male children become net producers at as early an age as 12 years, and work as many hours a day as an adult. Using a zero (calorie) rate of interest, he calculated that male children compensate for their own cumulative consumption by the age of 15. This is almost certainly not typical in Bangladesh today. I cite it, nevertheless, to show the vast difference in the motivation for having children between households in rich countries and poor households in poor countries. The latter would appear to need many hands, and it can be that the overall usefulness of each additional hand increases with declining resource availability, at least over some range.

The need for many hands can lead to a destructive situation, especially when parents do not have to pay the full price of rearing their children, but share those costs with their community. In Section 5 it was noted that in recent years mores that once regulated local resources have changed. We noted also that the very process of economic 
development can erode traditional methods of control, say, by way of increased urbanization and mobility. Social norms are also endangered by civil strife and by the usurpation of resources by landowners or the state. As norms degrade, parents pass some of the costs of children on to the community by over-exploiting the commons. Indeed, even a marginal decline in compliance in agreements can trigger a process of cumulative causation. Over time the effect could be large. If access to shared resources continues, parents produce too many children, which leads to greater crowding and susceptibility to disease as well as to more pressure on the local resource base. This is an instance of the demographic free-rider problem.

The perception of both low costs and high benefits of procreation in sub-Saharan Africa induces "couples" to produce too many children. Theoretical considerations suggest that in certain circumstances a disastrous process can thereby begin. As the community's natural resources are depleted, more hands are needed to gather fuel and water for daily use. More children are then produced, further damaging the local resource base and in turn providing the "household" with an incentive to enlarge. When this happens, poverty, fertility, and environmental degradation reinforce one another in an escalating spiral. By the time some countervailing set of factors - whether public policy or diminished benefits from having further children due, say, to a scarcity of land - stops the spiral, millions of lives may have suffered through worsening poverty. ${ }^{17}$

Cleaver and Schreiber (1994) provide evidence for this thesis in the context of rural sub-Saharan Africa, and Filmer and Pritchett (1996) for the Sindh region in Pakistan. They report positive correlations between fertility and deterioration of the local environmentalresource base. Such data cannot reveal causal connections, but they are not inconsistent with the idea of a positive-feedback mechanism such as I have described. Over time, the spiral would be expected to have large effects, as manifested by battles for resources (Homer-Dixon, Boutwell and Rathjens, 1993). Civic disconnection, a powerful destroyer

${ }^{17}$ Nerlove and Meyer (1997) has provided a formal analysis of such positive feedback processes. 
of property rights, can vastly reduce the rate of return on private investment in the local environmental-resource base. We should not be surprised, therefore, that it too is associated with degradation of the resource-base (Deacon, 1994).

Families with greater access to resources would, however, be in a position to limit their size and propel themselves into still higher income levels. $I$ have not been able to locate published data on the matter, but my impression is that among the urban middle classes in north India the transition to a low fertility rate has already been achieved. As we observed in Section III, this does not mean there is an inexorable poverty trap. People from the poorest of backgrounds have been known to lift themselves out of the mire. Nevertheless, there are these additional forces at work which pull households away from one another in terms of their living standards.

In this background, it is hard to make sense of the oft-expressed suggestion that there are cumulative benefits to be enjoyed from increases in population size even in poor countries; that human beings are a valuable resource. To be sure, they are potentially valuable as doers of things and originators of ideas, but for this they require the means for personal development. Moreover, historical evidence on the way pressure of population led to changes in the organization of production, property rights, and ways of doing things, which is what Boserup (1981) studied in her far-reaching work, also does not seem to speak to the population problem as it exists today in sub-Saharan Africa and the northern parts of the Indian sub-continent.

\section{Living Standards Indices}

World food production has on average more than kept pace with world population since the end of the Second World War. This has been accompanied by improvements in a number of indicators of human well-being, such as the infant survival rate, life expectancy at birth, and literacy. It is possible such statistics as these have given economists and demographers a license to ignore ecology. The problem is that these conventional indicators of the standard of living pertain to commodity production, not to the environmental-resource base upon which all production ultimately depends. They do not say if, for example, increases in gross national product (GNP) per head are not being realized by means of a depletion of natural capital; in particular, if increases in agricultural 
production are not being achieved by a "mining" of the soil and water tables. By concentrating on GNP (and other current-welfare measures, such as life expectancy at birth), rather than net national product (NNP), we wrongly bypass these concerns.

In what is now an extensive literature, it has been shown that if NNP is to function effectively as an index of social well-being, it ought to be estimated by deducting from GNP not only the depreciation of physical and human capital, but also the depreciation of natural capital and the social losses incurred because of increases in stocks of environmental pollution. But then it is possible for GNP per head to increase for an extended period even while NNP per head is declining. We should be in a position to say if this has been happening in poor countries; or, for that matter, if it has been happening in rich countries. But the practice of national-income accounting has lagged so far behind its theory, that we have little idea of what the facts have been. The problem is not that we do not know what items NNP should ideally contain; rather, it is that we do not have adequate estimates of the prices of environmental resources with which to measure the value of changes in resource stocks. Estimation of the accounting prices of environmental resources should now be high on the agenda of research in development economics.

Current estimates of NNP are biased because a biased set of prices is in use: prices imputed to environmental resources on site are usually zero, and this amounts to regarding the depreciation of environmental capital as zero. But this in turn means that profits attributed to investment projects that degrade the environment are higher than their social profits. A consequence is that wrong sets of projects get selected, in both the private and public sectors.

One can go further: the bias extends to the prior stage of research and development. When environmental resources are underpriced, there is little incentive on anyone's part to develop technologies that economise on their use. The extent of the distortion created by this underpricing will vary from country to country. Poor countries inevitably have to rely on the flow of new knowledge produced in advanced industrial economies. Nevertheless, poor countries need to have the capability for basic research. The structure of accounting prices there is likely to be different from those in advanced industrial countries, most especially for non-traded goods and services. Even when it is publicly 
available, basic knowledge is not necessarily usable by scientists and technologists, unless they themselves have a feel for basic research. Often enough, ideas developed in foreign Iands are merely transplanted to the local economy; whereas, they ought instead to be modified to suit local ecological conditions before being adopted. This is where the use of accounting prices is of help. It creates the right set of incentives, both among developers and users of technologies. Adaptation is itself a creative exercise. Unhappily, as matters stand, it is often bypassed. There is loss in this.

\section{Conclusions}

This article has been about the links that have recently been uncovered between poverty, high fertility and undernourishment, on the one hand, and degradation of the local environmental-resource base and civic disconnection, on the other, in poor countries. We have noted that while some of the policy implications of this new perspective are commonplace enough (e.g. the need for secure property rights), others are not so, at least they were not a commonplace until recently (e.g. the need for strengthening local democracy, and that direct measures for poverty eleviation are not incongruent with measures that enhance aggregate economic performance).

The new perspective takes high fertility rates in sub-Saharan Africa and the Indian sub-continent seriously and links it to environmental deterioration. It suggests that the most potent avenue open for bringing down fertility rates in the semi-arid regions of these continental masses involves the simultaneous deployment of a number of policies, not a single panacea, and that the relative importance of the various prongs would depend on the community in question. Thus while family-planning services (especially when allied to public-health services) and measures that empower women (through both education and improved employment opportunities) are certainly desirable policies, there are others, such as those that involve the provision of infrastructural goods (e.g. cheap sources of household fuel and potable water), and measures that directly increase the economic security of the poor. The aim should not be to force people to change their reproductive behaviour; rather, it should be to identify policies that would so change the options men and women face that their reasoned choices would involve a lowering of their fertility rates to replacement levels and a sustainable use of their resource base. 
While I have laid stress on the importance today of local democracy for the protection of the local environmental-resource base, evidence also suggests that even at the national level, political and civil liberties are positively correlated with improvements in income per head, life expectancy at birth, and the infant survival rate, and are negatively correlated with fertility rates. ${ }^{18}$ We are, therefore, encouraged to think that political and civil liberties have instrumental value, even in poor countries; they are not merely desirable ends. But each of the prescriptions offered by the new perspective is desirable in itself, and commends itself even when we do not have the population problem or environmental degradation in mind. It seems to me this consonance of means and ends is a most agreeable fact.

${ }^{18}$ See Dasgupta (1990), Przeworski and Limongi (1995), and Barro (1996). 


\section{REFERENCES}

Alderman, H. et al (1995), "Unitary versus Collective Models of the Household: Is it Time to Shift the Burden of Proof?" World Bank Research Observer, 10(1), 1-20.

Baland, J.-M. and J.-P. Platteau (1996), Halting Degradation of Natural Resources: Is There a Role for Rural Communities? (Oxford: Clarendon Press).

Bardhan, P. (1996), "Research on Poverty and Development Twenty Years after Redistribution with Growth", Proceedings of the Annual World Bank Conference on Development Economics, 1995 (Supplement to the World Bank Economic Review and the World Bank Research Observer), 59-72.

Barro, R.J. (1996), "Democracy and Growth", Joumal of Economic Growth 1(1), 1-27.

Bauer, P. and Yamey, B. (1968), Markets, Market Control and Marketing Reform (London: Weidenfeld \& Nicolson).

Press).

Becker, G. (1981), A Treatise on the Family (Cambridge, MA: Harvard University

Beteille, A. ed. (1983), Equality and Inequality: Theory and Practice (Delhi: Oxford University Press).

Bledsoe, C. (1990), "The Politics of Children: Fosterage and the Social Management of Fertility Among the Mende of Sierra Leone," in W. Penn Handwerker, Births and Power: social change and the politics of reproduction (London: Westview Press).

Boserup, E. (1981), Population Growth and Technological Change (Chicago: Chicago University Press).

Braverman, A. and J.E. Stiglitz (1989), "Credit Rationing, Tenancy, Productivity, and the Dynamics of Inequality", in P. Bardhan, ed., The Economic Theory of Agrarian Institutions (Oxford: Oxford University Press).

Brown, L.R. (1995), Who Will Feed China? Wake-Up Call for a Small Planet (New York: W.W. Norton).

Cain, M. (1977), "The Economic Activities of Children in a Village in Bangladesh," Population and Development Review 3, 201-27.

Cain, M. (1981), "Risk and Insurance: Perspectives on Fertility and Agrarian Change in India and Bangladesh," Population and Development Review 7, 435-74. 
Caldwell, J. (1991), "The Soft Underbelly of Development: Demographic Transition in Conditions of Limited Economic Change," Proceedings of the Annual Bank Conference on Development Economics 1990 (Supplement to the World Bank Economic Review and the World Bank Research Observer), 207-54.

Cassidy, J. (1996), "The Decline of Economics", New Yorker, December 2, 50-64.

Cleaver, K. M. and G.A. Schreiber (1994), Reversing the Spiral: the population, agriculture, and environment nexus in sub-Saharan Africa (Washington, D.C.: World Bank).

Coale, A.J. (1969), "The Decline of Fertility in Europe from the French Revolution to World War II," in J. Behrman, L. Corsa and R. Freedman, ed., Fertility and Family Planning: a world view (Ann Arbor, Michigan: University of Michigan Press).

Coleman, J. (1990), Foundations of Social Theory (Cambridge, MA: Harvard University Press).

C.S.E. (1990), Human-Nature Interactions in a Central Himalayan Village: a case study of village Bemru (New Delhi: Centre for Science and Environment). Press).

Dasgupta, P. (1982), The Control of Resources (Cambridge, MA: Harvard University

Dasgupta, P. (1990), "Well-Being and the Extent of its Realization in Poor Countries," Economic Journal, 100 (Supplement), 1-32. Press).

Dasgupta, P. (1993), An Inquiry into Well-Being and Destitution (Oxford: Clarendon

Dasgupta, P. (1995a), "Population, Poverty, and the Local Environment", $\underline{\text { Scientific }}$ American, 272(2), 40-45.

Dasgupta, P. (1995b), "The Population Problem: Theory and Evidence", Lournal of Economic Literature, 33, 1879-1902.

Dasgupta, P. (1996), "The Economics of the Environment", Environment and Development Economics, 1, 387-421.

Dasgupta, P. (1997a), "Nutritional Status, the Capacity for Work and Poverty Traps", lournal of Econometrics, 77, 5-37.

Dasgupta, P. (1997b), "The Economics of Food", in J.C. Waterlow, D.G. Armstrong, L. Fowden and R. Riley ed., Feeding a World Population of More than Eight Billion People: 
A Challenge to Science (New York: Oxford University Press), forthcoming 1998.

Dasgupta, P. (1997c), "Economic Development and the Idea of Social Capital", mimeo., Faculty of Economics, University of Cambridge.

Dasgupta, P. and K.-G. Mäler (1991), "The Environment and Emerging Development Issues", Proceedings of the Annual World Bank Conference on Development Economics, 1990 (Supplement to the World Bank Economic Review and the World Bank Research Observer), 101-132.

Dasgupta, P. and D. Ray (1986), "Inequality as a Determinant of Malnutrition and Unemployment: Theory", Economic Journal, 96, 1011-1034.

Dasgupta, P. and D. Ray (1987), "Inequality as a Determinant of Malnutrition and Unemployment: Policy", Economic Journal, 97, 177-188.

Deacon, R.T. (1994), "Deforestation and the Rule of Law in a Cross Section of Countries", Land Economics, 70(4), 414-430.

Deininger, K. and L. Squire (1997), "Economic Growth and Income Inequality: Reexamining the Links", Finance and Development, 34(1), 38-41.

Ensminger, J. (1990), "Co-opting the Elders: The Political Economy of State Incorporation in Africa", American Anthropologist, 92, 662-75.

Falconer, J. (1990), The Major Significance of 'Minor' Forest Products (Rome: Food and Agriculture Organization).

FAO (1992), "World Food Supplies and Prevalence of Chronic Undernutrition in Developing Regions as Assessed in 1992", Document ESS/MISC/1/92, Food and Agriculture Organization, Rome.

Feder, E. (1977), "Agribusiness and the Elimination of Latin America's Rural Proletariat", World Development, 5(5-7), 559-571.

Feeny, D. et al. (1990), "The Tragedy of the Commons: Twenty-two Years Later", Human Ecology 18(1), 1-19.

Filmer, D. and L. Pritchett (1996), "Environmental Degradation and the Demand for Children", Research Project on Social and Environmental Consequences of GrowthOriented Policies, Working Paper No. 2, World Bank, Washington, D.C.

Fogel, R.W. (1994), "Economic Growth, Population Theory, and Physiology: The Bearing of Long-Term Processes on the Making of Economic Policy", American Economic 
Review, 84(3), 369-395.

Freedman, R. (1995), "Asia's Recent Fertility Decline and Prospects of Future Demographic Change", Asia-Pacific Population Research Report No. 1, East-West Center, Honolulu.

Goody, E. (1982), Parenthood and Social Reproduction: Fostering and Occupational Roles in West Africa (Cambridge: Cambridge University Press).

Guyer, J.L. (1994), "Lineal Identities and Lateral Networks: The Logic of Polyandrous Motherhood," in C. Bledsoe and G. Pison (ed.), Nupitality in Sub-Saharan Africa: contemporary anthropological and demographic perspectives (Oxford: Clarendon Press).

Hajnal, J. (1982), "Two Kinds of Preindustrial Household Formation Systems," Population and Development Review, 8(3), 449-94.

Hardin, G. (1968), "The Tragedy of the Commons", Science, 162, 1243-48.

Hecht, S. (1985), "Environment, Development, and Politics: Capital Accumulation and the Livestock Sector in Eastern Amazonia", World Development 13(6), 663-684.

Hecht, S., A.B. Anderson and P. May (1988), "The Subsidy from Nature: Shifting Cultivation, Successional Palm Forests and Rural Development", Human Organization, $47(1), 25-35$.

Heilbroner, R. (1993), 21st Century Capitalism (New York: W.W. Norton).

Heilbroner, R. and W. Milberg (1995), The Crisis of Vision in Modern Economics (Cambridge: Cambridge University Press).

Homer-Dixon, T, J. Boutwell, and G. Rathjens (1993), "Environmental Change and Violent Conflict," Scientific American, 268(2), 16-23.

Howe, J. (1986), The Kuna Gathering (Austin, Texas: University of Texas Press).

IFPRI (1995), A 2020 Vision for Food, Agriculture, and the Environment (Washington, D.C.: International Food Policy Research Institute).

James, W.F.T. et al. (1992), Body Mass Index: An Objective Measure of Chronic Energy Deficiency in Adults (Rome: Food and Agriculture Organization).

Jodha, N.S. (1980), "The Process of Desertification and the Choice of Interventions", Economic and Political Weekly 15(32), 1351-56. 
Jodha, N.S. (1986), "Common Property Resources and the Rural Poor", Economic and Political Weekly 21(27), 1169-81.

Jodha, N.S. (1995), "Common Property Resources and the Environmental Context: Role of Biophysical versus Social Stress", Economic and Political Weekly, 30(51), 3278-83.

Krueger, A.O., M. Schiff and A. Valdes (1988), "Agricultural Incentives in Developing Countries: Measuring the Effect of Sectoral and Economywide Policy", World Bank Economic Review, 2(3), 255-272.

McKean, M. (1992), "Success on the Commons: A Comparative Examination of Institutions for Common Property Resource Management", Journal of Theoretical Politics, 4, 256-68.

Morris, M.D. (1979), Measuring the Condition of the World's Poor: The Physical Quality of Life Index (Oxford: Pergamon).

Myrdal, G. (1944), An American Dilemma: The Negro Problem and Modern Democracy (New York: Harper \& Row).

Nerlove, M. and A. Meyer (1997), "Endogenous Fertility and the Environment: A Parable of Firewood," in P. Dasgupta and K.-G. Mäler ed., The Environment and Emerging Development Issues, Vol.1 (Oxford: Clarendon Press).

Ostrom, E. (1990), Governing the Commons: The Evolution of Institutions for Collective Action (Cambridge: Cambridge University Press).

Ostrom, E. (1996), "Incentives, Rules of the Game, and Development", Proceedings of the Annual World Bank Conference on Development Economics, 1995 (Supplement to the World Bank Economic Review and the World Bank Research Observer), 207-34.

Pinstrup-Andersen, P. (1994), "World Food Trends and Future Food Security", Food Policy Report, International Food Policy Research Institute, Washington, D.C.

Platteau, J.-P. and Y. Hayami (1997), "Resource Endowments and Agricultural Development: Africa vs. Asia", in M. Aoki and Y. Hayami ed., The Institutional Foundation of Economic Development in East Asia (London: MacMillan), forthcoming, 1998.

Prosterman, R.L., T. Hanstad and Li Ping (1996), "Can China Feed Itself?", Scientific American, 275(5), 70-77.

Przeworski, A. and F. Limongi (1995), "Democracy and Development," Working Paper \#7, Chicago Center on Democracy, University of Chicago. 
Putnam, R. D., with R. Leonardi and R.Y. Nanetti (1993), Making Democracy Work: Civic Traditions in Modern Italy (Princeton, NJ: Princeton University Press).

Rudra, A. (1984), "Local Power and Farm-Level Decision-Making", in M. Desai, S.H. Rudolph and A. Rudra, ed., Agrarian Power and Agricultural Productivity in South Asia (Berkeley, CA: University of California Press).

Schneider, R. (1995), "Government and the Economy on the Amazon Frontier", World Bank Environment Paper No. 11, World Bank, Washington, D.C.

Sen, A. (1983), "Development: Which Way Now?", Economic Journal, 93, 745-62.

Serra, R. (1996), An Economic Analysis of Child Fostering in West Africa, Ph.D. Dissertation, Faculty of Economics, University of Cambridge.

Solorzano, R. et al. (1991), Accounts Overdue: Natural Resource Depreciation in Costa Rica (Washington, D.C.: World Resources Institute).

Spurr, G.B. (1988), "Marginal Malnutrition in Childhood: Implications for Adult Work Capacity and Productivity", in: K.J. Collins and D.F. Roberts, eds., Capacity for Work in the Tropics (Cambridge: Cambridge University Press).

Spurr, G.B. (1990), "The Impact of Chronic Undernutrition on Physical Work Capacity and Daily Energy Expenditure", in: G.A. Harrison and J.C. Waterlow, eds., Diet and Disease in Traditional and Developing Countries (Cambridge: Cambridge University Press). 597-685.

Stern, N. (1989), "The Economics of Development: A Survey", Economic lournal, 99,

UNDP (1994), Human Development Report (New York: Oxford University Press).

Wade, R. (1988), Village Republics: Economic Conditions for Collective Action in South India (Cambridge: Cambridge University Press).

Waterlow, J.C. (1992), Protein Energy Malnutrition (Sevenoaks, Kent: Edward Arnold).

WHO (1985), Energy and Protein Requirements (Geneva: World Health Organization).

World Bank (1986,1990,1991, 1994), World Development Report (New York: Oxford University Press), published annually. 
Yotopoulos, P. (1985), "Middle-Income Classes and Food Crises: The "New" FoodFeed Competition", Economic Development and Cultural Change, 33(3), 463-484. 